\title{
Kandungan Klorofil-a dan Kelimpahan di Perairan Kendal, Jawa Tengah
}

\author{
Bonita Nindya Garini*, Jusup Suprijanto, Ibnu Pratikto \\ Departemen IImu Kelautan, Fakultas Perikanan dan IImu Kelautan, Universitas Diponegoro \\ JI. Prof. H. Soedarto S.H, Tembalang,Semarang, Jawa Tengah 50275 Indonesia \\ ${ }^{*}$ Corresponding author, e-mail : nnindyag@gmail.com
}

\begin{abstract}
ABSTRAK: Kondisi perairan suatu wilayah memiliki tingkat kesuburan yang berbeda - beda salah satunya pada Perairan Jawa khususnya bagian utara. Perairan Utara Jawa memiliki kondisi arus dan gelombang yang cukup stabil dimana hal ini berpengaruh terhadap kandungan yang terdapat di dalamnya. Perairan Kendal merupakan salah satu perairan yang terletak di Utara Jawa yang dimanfaatkan dalam kegiatan perikanan. Kendal merupakan Kabupaten yang memiliki hasil tangkapan ikan yang cukup besar yang dimanfaatkan masyarakat untuk kehidupan sehari- hari. Kabupaten Kendal juga terkenal dengan kegiatan industri seperti industri Kayu Lapis. Kegiatan industri berdampak terhadap kondisi perairan di Kendal karena buangan limbah cair maupun padat yang dapat mempengaruhi tingkat kesuburan. Tingkat sesuburan perairan dapat dilihat salah satunya dari kandungan klorofil-a yang terdapat di dalamnya. Kandungan klorofil-a pada perairan dapat dilihat melalui banyaknya fitoplankton karena fitoplankton merupakan penghasil klorofil-a tertinggi di perairan. Tujuan dari penelitian ini adalah untuk mengetahui kualitas Perairan Kendal dilihat dari kandungan klorofil-a dan fitoplankton. Metode yang digunakan dalam penelitian ini adalah metode deskriptif, metode deskripstif dimaksudkan untuk mendapatkan gambaran tentang kualitas perairan melalui sebaran kandungan spasial klorofil-a pada Perairan Kendal. Teknik penentuan lokasi sampling dan pengambilan sampel menggunakan metode purpose sampling. Pengambilan data lapangan dilakukan sebanyak 10 titik. Titik lokasi ditandai menggunakan Global Positioning System. Hasil yang didapatkan dari penelitian menunjukkan hasil persebaran konsentrasi klorofil-a pada masing - masing stasiun berbeda dan hasil kelimpahan fitoplankton yang di dapatkan juga berbeda tetapi sesuai dengan konsentrasi klorofil-a pada masing - masing stasiun. Perbedaan disebabkan karena adanya faktor perbedaan lokasi sampling. Konsentrasi klorofil yang tertinggi terdapat pada stasiun 6 sebesar $1,7025 \mathrm{mg} / \mathrm{m}^{3}$ dan kelimpahan fitoplankton tertinggi juga pada stasiun 6 sebanyak $43.373 \mathrm{sel} / \mathrm{L}$.
\end{abstract}

Kata kunci: Kualitas Perairan; Klorofil-a; Fitoplankton; Perairan Kendal

\section{Chlorophyll-a Content and Abundance in The Waters of Kendal, Central Java}

ABSTRACT: The condition of the waters of an area has different fertility levels - one of which is in the Java waters especially in the north. The waters of North Java have relatively stable currents and waves which affect the content contained therein. Kendal waters is one of the waters located in North Java that is used in fisheries activities. Kendal is a regency that has a large enough fish catch that is utilized by the community for daily life. Kendal Regency is also famous for industrial activities such as the Plywood Industry. Industrial activities have an impact on water conditions in Kendal because of liquid and solid waste discharges that can affect fertility. Water fertility can be seen one of them from the content of chlorophyll-a contained in it. Chlorophyll-a content in water can be seen through the number of phytoplankton because phytoplankton is the highest chlorophyll-a producer in water. The purpose of this study was to determine the quality of Kendal Waters in terms of chlorophyll-a and phytoplankton content. The method used in this research is descriptive method, descriptive method is intended to get a picture of the quality of waters through the distribution of spatial content of chlorophyll-a in Kendal waters. The technique of determining the location of sampling and sampling uses the purpose sampling method. Field data collection was carried out by 10 points. Location points are marked using the Global Positioning System. The results obtained from the study showed that the distribution of chlorophyll-a concentrations at each station was different and the results of the abundance of phytoplankton obtained were also different but in accordance with the concentration of chlorophyll-a at each station. The 
difference is due to the sampling location difference factor. The highest chlorophyll concentration was found at station 6 at $1.7025 \mathrm{mg} / \mathrm{m}^{3}$ and the highest phytoplankton abundance was also at station 6 as many as 43,373 cells/L.

Keywords: Kendal Waters; Chlorophyll-a; Phytoplankton.

\section{PENDAHULUAN}

Kabupaten Kendal memiliki wilayah pesisir dengan Panjang pantai 43,5 km yang terbentang di 25 kelurahan atau desa. Kabupaten Kendal memiliki sekitar $47 \%$ wilayah pesisir yang tumbuh subur dan sisanya adalah dalam kondisi yang kurang subur (Pemerintah Kabupaten Kendal, 2012). Kabupaten Kendal memiliki berbagai kegiatan salah satunya adalah kegiatan perindustrian yang cukup tinggi. Menurut Setyawan dan Pamungkas (2017), wilayah Perairan Kendal merupakan wilayah yang terletak di utara yang memiliki kondisi perairan cukup tenang, seperti gelombang dan arus yang konstan sesuai dengan musim, berbeda dengan perairan selatan yang memiliki gelombang tinggi dan arus yang kuat. Menurut Adinugroho et al. (2014), di Kendal terdapat industri Kayu Lapis dan pelabuhan hal ini berpotensi mencemari lingkungan. Berkembangnya kegiatan penduduk di perairan pesisir pantai Kabupaten Kendal seperti bertambahnya pemukiman penduduk, kegiatan industri dan pertambakan, selain itu juga terdapat akivitas di laut seperti kegiatan penangkapan dan industri. Perairan laut Kendal merupakan zona penangkapan ikan sehingga kualitas dari produk hasil tangkapan dipengaruhi oleh kondisi kesuburan perairan (Hanifah et al., 2020). Kegiatan darat dan kegiatan laut di sekitar pesisir Kabupaten Kendal ini akan mempengaruhi kualitas perairan yaitu kesuburan perairan. Menurut Linus et al. (2016), kesuburan perairan biasanya dihubungkan dengan konsentrsi nutrien dalam badan peraian. Tinggi rendahnya kandungan klorofil-a memiliki keterkaitan dengan pasokan nutrien yang berasal dari darat melalui aliran sungai. Proses fotosintesis dipengaruhi oleh faktor konsentrasi klorofil-a dan intensitas cahaya matahari. Nilai produktivitas primer dapat digunakan sebagai indikasi tentang tingkat kesuburan suatu ekosistem perairan. Klorofil-a adalah suatu pigmen hijau yang dapat ditemukan pada algae, tumbuhan, dan cyanobacteria. Klorofil-a merupakan suatu pigmen aktif dalam sel tumbuhan yang mempunyai peranan penting dalam terjadinya proses fotosintesis di perairan yang dapat dijadikan sebagai indikator kesuburan perairan (Agung et al., 2018). Mengingat pigmen tersebut merupakan pigmen utama dari fitoplankton, sehingga konsentrasi fitoplankton dapat diidentifikasi (Sulistyah et al., 2016). Nilai konsentrasi klorofil-a pada fitoplankton dipengaruhi oleh faktor fisika kimia perairan dan faktor biologi. Berdasarkan penelitian yang sudah dilakukan Suprijanto et al. (2019), kandungan klorofil-a pada perairan Utara Jawa berkisar antara 0.4775-1.1849 $\mathrm{mg} / \mathrm{m}^{3}$. Dampak ekologis masuknya limbah organik dari daratan ke muara sungai membuat perairan menjadi lebih subur akibat peningkatan nutrien $\mathrm{N}$ dan $\mathrm{P}$. Nutrien ini merupakan substansi yang sangat berperan sangat nyata dalam proses dan perkembangan organisme hidup seperti fitoplankton. Fitoplankton akan terpengaruh seiring terjadinya perubahan kualitas perairan (Aminah et al., 2020). Tekanan yang terjadi di lingkungan berpengaruh terhadap kelimpahan dan distribusi plankton dan hal ini secara otomatis mempengaruhi kesuburan pada perairan tersebut. Penelitian ini dilakukan pada bulan Oktober 2019, dengan tujuan untuk mengetahui kualitas Perairan Kendal dilihat dari kandungan konsentrasi klororfil-a dan kelimpahan fitoplankton. Hasil penelitian diharapkan dapat menjadi sumber informasi yang bermanfaat bagi pengelolaan sumberdaya pesisir dan laut khususnya lingkungan Perairan Kendal dalam meningkatkan hasil perikanan.

\section{MATERI DAN METODE}

Materi yang digunakan dalam penelitian ini berupa klorofil-a, fitoplankton, sampel air dan pengamatan terhadap kualitas air meliputi suhu, salinitas, $\mathrm{DO}, \mathrm{pH}$, dan kecerahan. Data sampel air laut diambil dari Perairan Bandengan, Kabupaten Kendal yang selanjutnya dibawa ke laboraturium untuk dianalisis. Pengambilan sampel dilakukan pada bulan Oktober 2019. Data utama dalam 
penelitian ini berupa data spasial sebaran klorofil-a dan data kelimpahan fitoplankton Perairan Kendal. Adapun data pendukung meliputi data suhu, salinitas, $\mathrm{DO}, \mathrm{pH}$, dan kecerahan. Alat yang digunakan dalam pengambilan sampel adalah plankton net dengan ukuran 25 mikron untuk menyaring fitoplankton, DO meter untuk mengukur kadar DO, termometer untuk mengukur suhu, refraktometer untuk mengukur salinitas, $\mathrm{pH}$ meter untuk mengukur kadar $\mathrm{pH}$ dalam perairan secchi disk untuk mengukur tingkat kecerahan perairan. GPS (Global Positioning System) digunakan untuk mengetahui koordinat titil sampling, alat tulis untuk mencatat data hasil pengamatan. Mikroskop dan software scopel image digunakan untuk membantu analisis fitoplankton. Larutan formalin $4 \%$ digunakan sebagai pengawet plankton. Sedgwick rafter, buku identifikasi, pipet tetes digunakan untuk membantu analisa fitoplankton.

Metode yang digunakan dalam penelitian ini adalah metode deskriptif. Menurut Sugiyono (2009) metode deskriptif merupakan metode yang dimaksudkan untuk mendapatkan gambaran tentang kualitas perairan melalui sebaran kandungan spasial klorofil-a pada Perairan Kendal. Penentuan lokasi penelitian dilakukan berdasarkan metode purposive sampling dengan menggunakan GPS (Global Positioning System). Metode purposive sampling adalah teknik penentuan titik lokasi pengambilan sampel dengan pertimbangan tertentu sesuai dengan tujuan penelitian. Pengambilan sampel dilakukan pada 10 stasiun pengamatan.

Sampel air diambil menggunakan metode swap area dimana sampel air diambil menggunakan plankton net secara vertikal kurang lebih selama 10 menit tiap stasiun. Sampel air dimasukkan ke dalam botol sampel yang sudah diberi formalin 4\% dengan perbandingan 1:5 (Wardhana, 2005). Data kualitas air seperti suhu, salinitas, $\mathrm{pH}, \mathrm{DO}$, kecerahan diukur menggunakan alat seperti $\mathrm{pH}$ meter untuk mengetahui nilai $\mathrm{pH}$, DO meter untuk mengetahui nilai kandungan $\mathrm{DO}$, pengukuran salinitas menggunakan refractometer serta termometer untuk pengukuran suhu, dan secchi disk digunakan untuk mengukur tingkat kecerahan. Analisa fitoplankton dilakukan di laboraturium dengan menggunakan mikroskop serta lensa kamera dan software scopel image untuk mempermudah analisa fitoplankton. Analisa sebaran klorofil-a dilakukan menggunakan software envi 5.2 dengan melakukan kalibrasi radiometrik dengan menggunakan parameter Gain dan Offset yang tersedia dalam metdata citra. Data citra diunduh melalui portal USGS pada bulan Oktober 2019 (Sulistyah et al., 2016). Kemudian dilakukan pengolahan algoritma sampai dihasilkan sebaran konsentrasi klorofil-a. Data sebaran klorofil-a disajikan dalam bentuk peta menggunakan Software Arcgis 10.3

\section{HASIL DAN PEMBAHASAN}

Hasil analisia yang telah dilakukan untuk mengetahui konsentrasi klorofil-a dan kelimpahan fitoplankton serta dilakukan pengukuran parameter fisika dan kimia perairan menunjukkan bahwa kondisi Perairan Kendal tergolong ke dalam mesotrofik (tingkat kesuburan sedang). Perairan dengan tingkat kesuburan mesotrofik memiliki kandungan klorofil sebesar $\geq 1-3 \mathrm{mg} / \mathrm{m}^{3}$, dimana perairan mesotrofik merupakan status trofik berkadar sedang yang artinya unsur hara dalam perairan tersebut masih masuk dalam kategori sedang (Prihatin et al. 2018). Kesuburan perairan memiliki korelasi yang erat dengan status trofik dan sangat memungkinkan untuk dijadikan sebagai indikator penunjuk status trofik (Tammi et al. 2015). Konsentrasi sebaran klorofil-a di Perairan Kendal berkisar 1,3766-1,7025 mg/m³. Konsentrasi klorofil-a tertinggi terdapat pada stasiun 6 yaitu sebesar $1,7025 \mathrm{mg} / \mathrm{m}^{3}$ dan konsentrasi terendah terdapat pada stasiun 1 yaitu sebesar 1,3766 $\mathrm{mg} / \mathrm{m}^{3}$. Konsentrasi rata-rata klorofil-a sebesar $1,6399 \mathrm{mg} / \mathrm{m}^{3}$. Konsentrasi klorofil-a dapat dijadikan petunjuk untuk dalam menentukan status trofik suatu perairan (Linus et al., 2016). Kelimpahan fitoplankton di Perairan Kendal berkisar antara 4.076-43.373 sel/L. Kelimpahan terbesar terdapat pada stasiun 6 yaitu sebesar $43.373 \mathrm{sel} / \mathrm{L}$ dan kelimpahan terendah terdapat pada stasiun 1 yaitu sebesar $4.076 \mathrm{sel} / \mathrm{L}$. Rata-rata kelimpahan fitoplankton pada Perairan Kendal yaitu sebesar 33.622,2 sel/L. Komposisi fitoplankton yang ditemukan didominasi oleh kelas Bacillariophyceae dengan jumlah genus sebanyak 20 genus dari seluruh stasiun penelitian, dari kelas Dynophyceae sebanyak 2 genus, kelas Cyanophyceae sebanyak 1 genus dan kelas Chlorophyceae sebanyak 1 genus. Hasil analisis sebaran klorofil-a dapat dilihat pada Tabel 1 sedangkan hasil kelimpahan fitolpankton dapat dilihat pada Tabel 2. 
Tabel 1. Konsentrasi Klorofil-a pada 10 stasiun

\begin{tabular}{c|c}
\hline Stasiun & Nilai Klorofil $\left(\mathrm{mg} / \mathrm{m}^{3}\right)$ \\
\hline 1 & 1,3766 \\
2 & 1,6533 \\
3 & 1,6657 \\
4 & 1,7004 \\
5 & 1,6897 \\
6 & 1,7025 \\
7 & 1,6320 \\
8 & 1,6333 \\
9 & 1,6675 \\
10 & 1,6776 \\
\hline
\end{tabular}

Tabel 2. Kelimpahan Fitoplankton 10 stasiun

\begin{tabular}{c|c}
\hline Stasiun & Kelimpahan sel/L \\
\hline 1 & 4.076 \\
2 & 11.686 \\
3 & 26.307 \\
4 & 42.992 \\
5 & 41.634 \\
6 & 43.373 \\
7 & 42.232 \\
8 & 42.177 \\
9 & 40.438 \\
10 & 41.307 \\
\hline
\end{tabular}

Konsentrasi klorofil-a pada 10 stasiun memiliki nilai yang berbeda-beda. Stasiun 1 memiliki konsentrasi klorofil-a yang paling rendah, hal ini dikarenakan stasiun 1 terletak paling jauh dari muara sungai. Keberadaan muara sungai mempengaruhi nilai kesuburan dan kualitas perairan dalam suatu perairan. Muara sungai menjadi sumber masuknya nutrien dalam perairan karena masuknya limbah organik baik limbah pertambakan dan perikanan maupun limbah cair yang berasal dari kegiatan industri (Ramanda et al. 2017). Kabupaten Kendal memiliki kegiatan perikanan yang cukup menonjol, masyarakat wilayah pesisir Kabupaten Kendal mayoritas memiliki mata pencaharian sebagai nelayan dan untuk kehidupan sehari hari sangat menggantungkan dari hasil tangkapan ikan di perairan Kendal (Agung et al., 2018). Kualitas perairan sangat mempengaruhi hasil tangkapan nelayan dan tentunya berdampak pada kegiatan perikanan itu sendiri. Nilai sebaran konsentrasi klorofil-a menunjukkan pola yang sama dengan kelimpahan fitoplankton yang diperoleh. Pada penelitian yang dilakukan kelimpahan fitoplankton yang terendah dijumpai pada stasiun yang jauh dari muara sungai.

Kelimpahan fitoplankton terendah terdapat pada stasiun 1 dimana stasiun 1 merupakan stasiun yang berada paling jauh dari pesisir. Rendahnya kelimpahan fitoplankton pada stasiun 1 diduga karena kurangnya asupan organic pada perairan lepas pantai dan meningkatnya salinitas. Hal ini sesuai dengan pernyataan Nontji (2008) bahwa, salinitas dan suhu menentukan densitas perairan, dimana semakin dalam perairan suhu semakin rendah dan salinitas semakin meningkat, sehingga kerapatan air meningkat yang selanjutnya memengaruhi laju pertumbuhan fitoplankton dalam proses fotosintesis, yang akan mempengaruhi laju penenggelaman fitoplankton. Pada stasiun 1 tingkat kecerahan juga menunjukkan angka yang tinggi. Tingginya nilai kecerahan pada stasiun 1 juga diduga menyebabkan rendahnya kelimpahan fitoplankton yang berdampak pada kandungan klorofil-a. Pernyataan ini sejalan dengan pernyataan Hanifah et al. (2018) bahwa kecerahan yang tinggi menandakan bahwa perairan memiliki bahan organic yang sedikit sehingga konsentrasi fosfat rendah dimana fosfat adalah yang dibutuhkan oleh fitoplankton. Swayati et al. (2015) juga mengemukakan bahwa perairan dengan tingkat kesuburan eutrofik ringan, pada 
tingkat kesuburan ini perairan telah mengalami penurunan kecerahan air. Hal ini sejalan dengan penelitian bahwa semakin rendahnya kecerahan semakin tinggi kelimpahan fitoplankton dan kandungan klorofil-a.

Perairan Kendal berdasarkan rata-rata nilai kelimpahan fitoplankton tergolong memiliki tingkat kesuburan eutrofrik atau tingkat kesuburan tinggi. Kelimpahan fitoplankton lebih dari 15.000 $\mathrm{sel} / \mathrm{L}$ termasuk ke dalam tingkat kesuburan eutrofik (Raymont, 1963). Penelitian ini selaras dengan penelitian yang dilakukan Ramanda et al. (2017), bahwa kelimpahan fitoplankton pada perairan sungai Bodri yang mengarah ke laut lepas memiliki tinggkat kesuburan eutrofik. Melimpahnya fitoplankton di Perairan Kendal diduga karena adanya asupan organic dari sungai terutama sungai Bodri. Sungai Bodri merupakan sungai yang dikelilingi organic pertanian, pertambakan dan pemukiman warga. Aktivitas masyarakat seperti, penangkapan dan pengolahan ikan yang merupakan organic skala rumah tangga menghasilkan limbah yang mengakibatkan penambahan bahan organic secara signifikan.

Parameter penunjang selama penelitian yaitu suhu berkisar antara $30,8-32^{\circ} \mathrm{C}$ hal ini disebabkan oleh kondisi pada saat penelitian tidak jauh berbeda. Secara umum kisaran suhu selama penelitian sesuai dengan suhu yang dapat dimanfaatkan fitoplankton untuk tumbuh dan berkembang. Permanasari et al. (2017) mengemukakan bahwa suhu optimum untuk kehidupan plankton $25-30^{\circ} \mathrm{C}$, kisaran pada suhu $10-35^{\circ} \mathrm{C}$ dapat meningkatkan laju fotosintesis. Hal tersebut diperjelas dalam penelitian Ayuningsih et al. (2014) suhu yang tinggi dapat menaikkan laju maksimum fotosintesis. Secara umum, laju fotosintesis akan meningkat seiringnya meningkatnya suhu perairan, tetapi akan menurun secara drastis setelah mencapai suatu titik suhu tertentu. Hal ini disebabkan setiap spesies fitoplankton selalu beradaptasi terhadap suatu kisaran suhu tertentu. Salinitas berkisar 30-32 ppt salinitas terendah terdapat pada stasiun 2 dan 9 . Kisaran ini sesuai untuk pertumbuhan dan perkembangan fitoplankton serta bukan merupakan faktor pembatas (Yuliana et al., 2012). Rata-rata nilai salinitas pada stasiun akan semakin rendahh apabila letak stasiun semakin dekat dengan pesisir. Hal ini sesuai dengan yang dikemukakan Simanjuntak (2009) bahwa di perairan pantai yang bersalinitas rendah komunitas plankton lebih tinggi dari pada perairan yang letaknya jauh dari pantai yang bersalinitas tinggi. Hal ini berkaitan dengan hasil kelimpahan fitoplankton yag didapatkan bahwa stasiun yang dekat dengan pantai atau pesisir memiliki kelimpahan yang lebih banyak.

Kandungan $\mathrm{DO}$, kadar $\mathrm{pH}$, dan kecerahan adalah faktor yang mempengaruhi kualitas perairan selain suhu dan salinitas. Kadar DO berkisar antara 4,14-6,92 ppm dengan kadar tertinggi pada stasiun 9 dan kadar terendah pada stasiun 4. Kadar oksigen terlarut pada perairan ini termasuk ke dalam kondisi yang cukup baik. Menurut Ramanda et al. (2017) bahwa kondisi oksigen terlarut yang kurang baik untuk perairan akan menyebabkan efek yang kurang menguntungkan bagi hampir semua organisme akuatik. Kadar oksigen terlarut kurang dari $4 \mathrm{mg} / \mathrm{L}$ menimbulkan efek yang kurang menguntungkan bagi hampir semua organisme akuatik, kadar oksigen terlarut kurang dari $2 \mathrm{mg} / \mathrm{L}$ dapat mengakibatkan kematian (Ayuningsih et al. 2014).

Tabel 3. Hasil pengukuran parameter perairan penunjang penelitian

\begin{tabular}{cccccc}
\hline Stasiun & $\begin{array}{c}\text { Suhu } \\
\left({ }^{0} \mathrm{C}\right)\end{array}$ & $\begin{array}{c}\text { Salinitas } \\
(\mathrm{ppt})\end{array}$ & $\begin{array}{c}\mathrm{DO} \\
(\mathrm{ppm})\end{array}$ & $\mathrm{pH}$ & $\begin{array}{c}\text { Kecerahan } \\
(\mathrm{cm})\end{array}$ \\
\hline 1 & 31 & 31 & 5.67 & 8,1 & 37,5 \\
2 & 30,9 & 30 & 5.8 & 8 & 35 \\
3 & 32 & 30.8 & 4.25 & 7,8 & 50 \\
4 & 31 & 30.5 & 4.14 & 7,9 & 29 \\
5 & 31 & 32 & 6.2 & 7,8 & 30 \\
6 & 32 & 31 & 5.36 & 7,9 & 27,5 \\
7 & 31,4 & 32 & 5.58 & 8 & 17,5 \\
8 & 32 & 32 & 6.7 & 7,5 & 27,5 \\
9 & 31,3 & 30 & 6.92 & 7,5 & 14 \\
10 & 30,8 & 32 & 5.91 & 7,2 & 17,5 \\
\hline
\end{tabular}


Nilai derajat keasaman atau nilai $\mathrm{pH}$ yang didapatkan berkisar antara 7,2 - 8,1. Menurut KEPMEN LH (2004) bahwa kondisi derajat keasaman yang optimal untuk kehidupan fitoplankton berkisar antara 7-8,5. Nilai pH dipengaruhi oleh beberapa faktor antara lain seperti fotosintesis dan respirasi, suhu, dan keberadaan ion - ion dalam perairan dimana terjadinya fotosintesis akan terjadi secara optimal apabila nilai pH dalam keadaan normal (Pratiwi et al., 2015).

Nilai kecerahan di 10 stasiun pengamatan berkisar antara $14-50 \mathrm{~cm}$, dimana pada stasiun 9 nilai kecerahan termasuk ke dalam nilai yang paling rendah. Hal tersebut diduga karena adanya proses mixing yang menyebabkan sedimen dibawah perairan teraduk sampai ke permukaan perairan. Jika dalam suatu perairan nilai kecerahan rendah maka hal ini menyebabkan proses fotosintesis tidak terjadi secara optimal. Hal ini sesuai dengan yang dikemukakan Hikmawati et al. (2014) bahwa kuranganya cahaya matahari yang masuk ke dalam perairan akan menyebabkan kurang optimumnya proses fotosintesis, sehingga berpengaruh pada klorofil-a dimana kelimpahan fitoplankton dapat menggambarkan konsentrasi klorofil-a. Semakin tinggi kelimpahan fitoplankton, maka akan semakin tinggi nilai klorofil-a yang menggambarkan biomasa fitoplankton. Hal ini berbeda dengan hasil penelitian yang dilakukan bahwa semakin nilai kecerahan rendah semakin banyak kandungan klorofil-a dan kelimpahan fitoplankton. Hasil penelitian ini didukung oleh pernyataan Hanifah et al. (2018) bahwa kecerahan yang tinggi menandakan bahwa perairan memiliki bahan organik yang sedikit sehingga konsentrasi fosfat rendah dimana fosfat adalah nutrien yang dibutuhkan oleh fitoplankton.

\section{KESIMPULAN}

Berdasarkan kandungan klorofil-a, kualitas Perairan Kendal tergolong ke dalam mesotrofik atau tingkat kesuburan sedang, dengan konsentrasi klorofil-a berkisar 1,3766-1,7025 mg/m³. Perairan Kendal berdasarkan kelimpahan fitoplankton termasuk ke dalam mesotrofik atau tingkat kesuburan sedang dengan kelimpahan berkisar 4.076-43.373 sel/L.

\section{DAFTAR PUSTAKA}

Adinugroho, M., Subiyanto, \& Haeruddin. 2014. Komposisi Dan Distribusi Plankton Di Perairan Teluk Semarang. Saintifika, 16(2):39-48.

Agung, A., Zainuri, M., Wirasatriya, A., Maslukah, L., Subardjo, P., Suryosaputro, A.A.D. \& Handoyo, G. 2018. Analisis Sebaran Klorofil-A dan Suhu Permukaan Laut sebagai Fishing Ground Potensial (Ikan Pelagis Kecil) di Perairan Kendal, Jawa Tengah. Buletin Oseanografi Marina, 7(2): 67-74.

Aminah, S., Nuraini, R.A.T. \& Djunaedi, A. 2020. Komposisi dan Kelimpahan Fitoplankton di Perairan Pandansari, Desa Kaliwlingi, Kabupaten Brebes, Jawa Tengah. Journal of Marine Research, 9(1):81-86.

Ayuningsih, M.S., Hendrarto, B. \& Purnomo, P.W. 2014. Distribusi Kelimpahan Fitoplankton Dan Klorofil-A Di Teluk Sekumbu Kabupaten Jepara : Hubungannya Dengan Kandungan Nitrat Dan Fosfat Di Perairan. Journal of Maquares., 3(2):138-147.

Hanifah, D.N., Wulandari, S.Y., Maslukah, L. \& Supriyantini, E. 2018. Sebaran Horizontal Konsentrasi Nitrat Dan Fosfat Anorganik Di Perairan Muara Sungai Kendal, Kabupaten Kendal. Journal of Tropical Marine Science, 1(1):27-32.

Hanifah, H., Suprijanto, J. \& Subagyo. 2020. Jumlah Total Bakteri dan Bakteri Coliform Pada Air Laut dan Sedimen Perairan Laut Kecamatan Kendal. Journal of Marine Research., 9(3):245250.

Hikmawati, N, Hartoko, A. \& Sulardiono, B. 2014. Analisa Sebaran Mpt, Klorofil-A Dan Plankton Terhadap Tangkapan Teri (Stolephorus Spp.) di Perairan Jepara. Diponegoro Journal of Maquares., 3(2):109-118. 
Linus, Y., Salwiyah \& Irawati, N. 2016. Status kesuburan perairan berdasarkan kandungan klorofila di Perairan Bungkutoko Kota Kendari. Jurnal Manajemen Sumber Daya Perairan, 2(1):101111.

MENLH (Menteri Negara Lingkungan Hiidup). 2004. Surat Keputusan Menteri Negara Lingkungan Hidup No.KEP-51/MENLH/2004 tentang Baku Mutu Air Laut untuk Biota Laut, Lampiran III.

Nontji, A. 2008. Plankton Laut. Pusat Penelitian Oseanografi. Lembaga IImu Pengetahuan Indonesia (LIPI). LIPI Press. 331 hal.

Pratiwi, E.D., Koenawan, C.J. \& Zulfikar, da A. 2015. Hubungan Kelimpahan Plankton Terhadap Kualitas Air di Perairan Malang Rapat Kabupaten Bintan Provinsi Kepulauan Riau. FKIP UMRAH.

Permanasari, S.W.A., Kusriani, \& Widjanarko, P. 2017. Tingkat Kesuburan Perairan Di Waduk Wonorejo Dalam Kaitannya Dengan Potensi Ikan. Journal of Fisheries and Marine Science, 1(2):88-94.

Prihatin, A., Setyomo, P. \& Sunarto. 2018. Sebaran Klorofil-a, Nitrat, Fosfat dan Plankton Sebagai Indikator Kesuburan Ekosistem di Mangrove Tapak Tugurejo Semarang. Jurnal IImu Lingkungan, 16(1):68-77.

Ramanda, O.A, Sulardiono, B. \& Ain, C. 2017. Analisa Kualitas Perairan Ditinjau Dari Tingkat Saprobitas Dan Kandungan Klorofil Di Muara Sungai Bodri Kendal. Journal of Maquares., 6(1):67-76.

Raymont, J.E.G. 1963. Plankton and Produktivity in the Ocean. Apergamon Press Book. The Macmilan CO. New York.

Republik Indonesia. 2012. Peraturan Daerah Kabupaten Kendal tentang Rencana Pembangunan Jangka Menengah Daerah Kabupaten Kendal. Kabupaten Kendal.

Setyawan, W.B. \& Pamungkas, A. 2017. Perbandingan Karakteristik Oseanografi Pesisir Utara Dan Selatan Pulau Jawa: Pasang-Surut, Arus, Dan Gelombang. Seminar Nasional Kelautan dan Perikanan III. Universitas Trunojoyo Madura, hlm.191 (abstrak).

Simanjuntak, M. 2009. Hubungan Faktor Lingkungan Kimia, Fisika Terhadap Distribusi Plankton Di Perairan Belitung Timur, Bangka Belitung. Jurnal Perikanan., 9(1):31-45.

Sugiyono. 2009. Metode Penelitian Kuantitatif dan Kualitatif. CV. Alfabeta: Bandung.

Sulistyah, U.D., Jaelani, L.M. \& Winarso, G. 2016. Validasi Algoritma Estimasi Konsentrasi Chl-A Pada Citra Satelit Landsat 8 Dengan Data In-Situ (Studi Kasus: Perairan Selatan Pulau Lombok, NTB). Jurnal Teknik ITS, 5(2):159-164.

Suprijanto, J., Widowati, I., Wirasatriya, A. \& Khasanah, U.N. 2019. Spatio-Temporal Distribution of Chlorophyll-a In The Northern Waters of Central Java Using Aqua-MODIS. IOP Publishing, 246.

Swayati, D.P., Muskananfola, M.R. \& Rudiyanti, S. 2015. Konsentrasi Klorofil-A, Nitrat Dan Fosfat Untuk Menilai Kesuburan Muara Sungai Wakak, Kendal. Journal of Maquares., 4(4): 71-79.

Tammi, T., Pratiwi, N.T. \& Radiarta, I.N. 2015. Aplikasi Analisis Klaster dan Indeks Trix untuk Mengkaji Variabilitas Status Trofik di Teluk Pegametan, Singaraja, Bali. Fakultas Perikanan dan IImu Kelautan. Institut Pertanian Bogor.

Wardhana, W. 2005. Teknik Sampling, Pengawetan, dan Analisis Plankton. Pelatihan Teknik Sampling dan Identifikasi Fitoplankton, Jakarta.

Yuliana, Adiwilaga, E.M., Harris, E. \& Pratiwi, N.T.M. 2012. Hubungan Antara Kelimpahan Fitoplankton dengan Parameter Fisik-Kimiawi Perairan Di Teluk Jakarta. Jurnal Akuatika 3(2):169-179. 